\title{
The explicit freedoms in our model democracy
}

Liberty isn't like a tap; it isn't something that can be turned ond off at will. Much the same can be said for freedom of speech, including the freedom of the media, and the freedom of citizens to use the media to express their views.

\section{By SIR RABBIE NAMALIU}

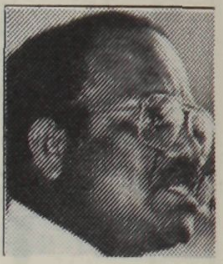

I'D LIKE to draw on my experience over the last 20 years or so from the unique standpoint of one who has served as head of Papua New Guinea's civil service, head of executive government, Leader of the Opposition, and, currently, head of the legislature, our National Parliament. I have been searching through the records of other Westminster model Parliaments, and I am unable to fine anyone else who has held all these pivotal positions in their career. I am not certain whether that is a plus or a minus.

I say that not to 'beat my own drum' but to remind you that I do not just speak as a former prime minister, or current Speaker of the National Parliament. I see there being three fundamental tenets for our democracy, apart from the national Constitution itself. The first is our National Parliament, and our free and open election process. The second is our independent and impartial judiciary ensuring the rule of law and respect for it by all. The third is freedom of expression, whether it be in the media, in community organisations, or in village debate and discussion. The three are dependent on each other for their strength, effectiveness and their future.

If we have significant weakness in, or restriction on, one sector, the others will be less effective, and the very basis of our democracy will be at risk from oppressive, totalitarian, undemocratic rule. Our national Constitution provides comprehensive guarantees for freedom of expression, freedom of the press, freedom of assembly and association, and even the right to freedom of information. 
These comprehensive provisions and protections did not come about by accident, by mistake or without extensive debate and deliberation. During the long consultative process which led to the development, and adoption, of our national Constitution I was working as a senior adviser to our first Chief Minister, Sir Michael Somare. As such I took, as did many others, a very close interest in the workings of the commission charged with the task of formulating our Constitution. Now the committee recommended, and the House of Assembly adopted, a parliamentary model based on the Westminster system, but departing from it in some quite important respects, notably the method of election, and removal, of a prime minister and a government. The commission again recommended, and the House adopted, a series of guaranteed freedoms such as those contained in sections 45,46 and 47 of the Constitution. These freedoms are far more explicit, and clear, than are those to be found in the constitutions of most countries, including the so-called 'model democracies'.

So when we consider the future freedom of the press, and freedom of expression, especially through the press and broadcast media, we need to remember that the freedoms entrenched in our Constitution were put there quite deliberately, by elected leaders well aware of the meaning and impact of their inclusion. Underpinning their inclusion was a passionate commitment to make Papua New Guinea a model democracy for the developing world, and a democracy in the truest, most unqualified way.

Now concern about press freedom as a fundamental requirement in a democracy is not new; it is not even a 20 th century invention. The third President of the United States and architect of the Declaration of Independence, Thomas Jefferson, said of press freedom that: 'The liberty of the press cannot be limited without being lost.'

Two centuries later, that is the most important question we must address when we consider any proposal to tamper with, or even review, the basic freedom of the press guaranteed by our Constitution. Press freedom is very much like personal liberty, and the liberty of the citizen of a nation as a whole. Once it is limited in any substantial way, it is effectively removed or quashed completely. Liberty is not like a tap, it is not something that can be turned on and off at will. Much the same can be said for freedom of speech, including freedom of the media, and the freedom of citizens to make use of the media to express their views, their frustrations, their hopes.

Having said these things, you would expect me to caution against attempts to limit media and press freedom. When such limits are proposed by politicians soon to face a general election, my caution is redoubled. The recent history of developing countries, and some developed ones as well, is littered with examples of oppression, totalitarian rule and injustice which began with 


\section{SIR RABBIE NAMALIU}

creeping controls over personal freedom, and over the freedom of the press.

Now I am not suggesting that recent proposals in our own country to limit press freedom are a first step towards dictatorship. The basic strength of our democracy, our ethnic diversity, and our entrenched love of freedom would always present a daunting challenge to dictatorship and oppressive rule. What I do suggest, and urge you to consider, is that our basic treedom of expression, and that of the press, is fundamental to national harmony, and to political accountability, as well as public confidence in the processes of democracy itself.

If we seek to further define, or even limit, these basic rights then the proper and necessary role of the media in encouraging debate, in exposing corruption and abuse, and in keeping politicians and governments accountable, can be clouded if not severely limited. They carry with them responsibilities.

As Prime Minister, I was often asked about our press freedom by visiting leaders, who were interested in the robust way our media, including state-owned radio, criticised political and other leaders. My response centred on my belief, and experience, that whatever shortcomings total press freedom may have had, it was far preferable to the alternative. And it was something our citizens genuinely had confidence in.

I am not certain that all our visitors went away convinced that they should follow our model, but I suspect there was a grudging admiration for our robust and healthy debate, and our capacity to manage differences without shooting each other, or resorting to some other extreme measures. The quite strong guarantees and protections for personal and for press freedom, contained in the national Constitution, were not an accident, but were put there by our founding fathers who were determined to see the emerging nation of Papua New Guinea as a robust and free democracy, and one in which tyranny, dictatorship and oppression could be resisted at every turn.

Essentially, we have been sell served by these guarantees, just as we have been extremely well served by an independent judiciary and the rule of law. I believe we all have a responsibility to defend these freedoms. The owners, and professional men and women who work in, the media have no less a responsibility to do so than do I as an elected leader who believes in a strong and robust democracy.

That statement brings me to the final point I want to make today. It concerns the role of the media in ensuring that accountability, and responsibility, underpin continuing public confidence in a free and open press. I am very wary of the term self-regulation, because it implies a watering down of the principles of media freedom. I would rather use the termaccountability, and accountability that is driven by the media industry itself.

The Australian Press Council, an organisation which was developed by the 88 PACIFIC JOURNALISM REVIEW 3:2 1996 
press industry, I am reliably informed enjoys wide respect for its integrity, and impartiality. I believe an industry-driven council, with appropriate teeth, can readily acquire the same level of respect in Papua New Guinea. As I understand it, the primary roles of the Press Council would be to help ensure high standards of ethics in reporting and publishing, and to provide a means by which aggrieved people may obtain some redress without having to go to the cost and time of action through the courts.

None of us is without fault. When deadlines must be met, and when controversial and complex issues must be addressed, genuine, innocent errors do occur. A readily accessible, independent means of redress for legitimate grievances needs to be available. When there are cases of more serious harm or injustice, the law of defamation is available to all. Such a council needs to be chaired by an independent, universally respected citizen, and the media needs to undertake to abide 100 per cent by any findings or recommendations.

It is perhaps a coincidence, but even parliaments based on the Westminster model have begun developing means whereby citizens wrongly or unfairly named under parliamentary privilege can obtain redress, such as through an appearance before the Parliament, or having their response read out in the House. It may well be that we ought to consider a similar approach in our Parliament.

I want to urge the media to address accountability, not just as a response to the Constitutional Commission review, but as a proactive measure to maintain public confidence in the media, and to help ensure the basic freedoms of the press, as outlined in the national Constitution, are not eroded or interfered with.

It is not just the responsibility of elected leaders to defend freedoms contained in the Constitution which are fundamental to our way of life. Those who enjoy and benefit from those freedoms have to defend them as well. With regard to the provisions of the Constitution, I urge that we all follow the simple saying, 'If it's not broken, why try to fix it.' These provisions have stood the test of time, they are envied by other countries, and they have been studies for their wisdom and their worth.

What I urge, in conclusion, is that the media, and all who believe in media freedom, defend these important safeguards, while at the same time acknowledging the need for the media to ensure it maintains high standards of reporting, and provide a fair means for aggrieved citizens to redress grievances and correct errors. If that happens, through initiatives such as this seminar, then you will have contributed to an actual strengthening of the important freedom of speech and publication you enjoy thanks to the founders of our Constitution.

$\square$ Sir Rabbie Namaliu, Speaker of the National Assembly, is a former Prime Minister of PNG. He gave this closing address at the 'Freedom at the Crossroads' news media seminar in Port Moresby on 29 February-1 March 1996. 